\title{
EFFECTS OF THERMAL PRE-TREATMENT AND VARIABLES OF PRODUCTION ON PROPERTIES OF OSB PANELS OF Pinus taeda
}

\author{
Rafael Farinassi Mendes ", Geraldo Bortoletto Júnior², Natalie Ferreira de Almeidaª, \\ Paula Gabriella Surdi ${ }^{3}$, Isabela Najm Barbeiro ${ }^{4}$
}

\begin{abstract}
The main objective of this study was to compare the effect of thermal pre-treatment in particles of strand type with the effect of variables of production on physical-mechanical properties of OSB panels, aiming to improve their dimensional stability. The experimental design consisted on five treatments with the assessment of two temperatures of thermal treatment on particles $\left(200\right.$ and $\left.240^{\circ} \mathrm{C}\right)$ during 60 minutes; the increase of adhesive content, the application of paraffin in different treatments and a control treatment. For each treatment three panels with Phenol-Formaldehyde adhesive were produced. The cycle of pressing panels was: pressure of $3.5 \mathrm{MPa}$ and temperature $160^{\circ} \mathrm{C}$ during 8 minutes. Analyzing the results of tests it was possible to conclude that: the thermal treatment of particles at $200^{\circ} \mathrm{C}$ promoted a negative effect on physical and mechanical properties, while thermal treatment of particles at $240^{\circ} \mathrm{C}$ promoted a significant improvement on physical properties and reduction of mechanical properties. The increase on adhesive content resulted in a significant improvement of WA24h, and the application of paraffin improved the WA2h and TS2h of panels, however such treatments were not so efficient on keeping the dimensional stability of OSB panels as a thermal treatment applied on particles at $240^{\circ} \mathrm{C}$.
\end{abstract}

Keywords: OSB, thermal pre-treatment, variables of production, physical-mechanical properties.

\section{INTRODUCTION}

OSB (Oriented Strand Board) panels are used in several applications, such as structural panels in walls, roofs, floors, components of beams, packaging, etc. The use of these panels has increased significantly and it has been occupying spaces that were once exclusive for plywood. However its main limitation against plywood is the low dimensional stability since that OSB, when in contact with moisture, presents higher thickness swelling.

In this context, several researches have been conducted in order to improve dimensional stability of wood and consequently of their products, for example: chemical modification (Hill and Mallon 1999, Chang and Chang 2003); bulking agents (Rowell 1981, Chen et al. 1995, Paz 2000); and thermal treatment (Gohar and Guyonet 1998, Kim et al. 1998, del Menezzi 2004, Brito et al. 2006, Pessoa 2006). Besides, there are other ways to search for the improvement of dimensional stability, which are related to the production of panels, and they are not considered specific treatments, such as the use of different types and contents of adhesives and addition of repellents of water, for example, paraffin (Moslemi 1974, Kelly 1977, Maloney 1993, Murakami et al. 1999, Wu 1999, Mendes 2001, Iwakiri et al. 2003).

\footnotetext{
Forest engineer, Ph.D. in Wood Science and Technology, Department of Forest Sciences/ DCF Universidade Federal de Lavras/UFLA. Cx P. 3037 37200-000 Lavras-MG/Brasil.

${ }^{2}$ Forest engineer, Teacher, Department of Forest Sciences / LCF Escola Superior de Agricultura Luiz de Queiroz / ESALQ-USP.

Cx P. 09 13418-000 Piracicaba-SP/Brasil, gbortoll@esalq.usp.br.

${ }^{3}$ Forest engineer, MSc in Forestry, Forest Sciences Department/LCF Escola Superior de Agricultura Luiz de Queiroz / ESALQ-USP.

Cx P. 09 13418-000 Piracicaba-SP/Brasil, nataliealmeida@usp.br; paulasurdi@usp.br.

${ }^{4}$ Agronomic Engineering, Department of Engineering, Escola Superior de Agricultura Luiz de Queiroz / ESALQ-USP. Cx P. 09 13418-000

Piracicaba-SP/Brasil, isabela.barbeiro@usp.br.

ACorresponding author: rafaelfarinassi@gmail.com

Received: 24.03.2012 Accepted: 22.09. 2012
} 
The thermal treatment consists on applying heat to the wood or in the wood products at temperatures of 100 and $250^{\circ} \mathrm{C}$, which will depend on the intended degree of modification. In the case of OSB panels, this treatment may be developed by two ways, one after the consolidated panel (post-treatment) and other applied on particles before the manufacture of the panel (pre-treatment). The result is the obtainment of a solid product presenting differentiated characteristics when compared to its original wood (BRITO et al. 2006), becoming an efficient method to improve the dimensional stability and biological resistance to xylophagous organisms of wood (Stamm 1956, Hillis 1984, Bourgois and Guyonnet 1988, Homan et al. 2000, Goroyias and Hale 2002, Momohara et al. 2003, Rousset et al. 2004, Paul et al. 2006, Paul et al. 2007).

Alterations on chemical composition of wood thermally treated and also of its products may explain many alterations observed in several properties. Thus, when the wood is heated, changes occur on the nature of its contents (cellulose, hemicelluloses, lignin and extractives), especially hemicelluloses (or polyoses) that is the most sensible component to the heat, what may modify its hygroscopicity, dimensional stability and permeability (Hillis 1984, Winandy and Krzysik 2007). According to Byrne and Nagle (1997), the most intense thermal degradation of polyoses starts at $200^{\circ} \mathrm{C}$. Such degradation causes changes on hygroscopicity, wood resistance to fungi, on color and mechanical properties. Tjeerdsma et al. (1998) and Tjeerdsma and Militz (2005) affirm that the decrease of hygroscopicity is provided by the reduction of accessibility to free hydroxyl groups (sites of sorption) and by the formation of furfural polymers, which are a result of degradation of sugar (hemicelluloses) that are less hygroscopic. While Santos (2000), Kubojima et al. (2000); del Menezzi (2004) e Paul et al. (2007) affirm that generally chemical and anatomic modifications of wood, resultant from thermal treatment, leads to alterations of their mechanical properties, reducing their value.

Nevertheless the most analyzed type for obtainment of OSB panels with better dimensional stability is related to the use of different types and contents of adhesives and also the addition of water repellents (paraffin). In the case of type and content of adhesive, most of the OSB industries use Phenol-Formaldehyde and MDI adhesive (Spelter et al. 2006), normally about 3.0 to 6.0\% (basis dry mass of particles) (Iwakiri et al. 2003). In the case of paraffin, its function is to provide the panel repellency to water in liquid state, and this reduction of hygroscopicity promotes the improvement of absorption properties and thickness swelling, however, the effect is significant only for short periods of time (Moslemi 1974).

Some studies reveal that both application of paraffin and different types and contents of adhesive have showed improvements related to dimensional stability of panels, mainly adhesive content, but without obtaining too pronounced outcomes (Moslemi 1974, Kelly 1977, Maloney 1993, Murakami et al. 1999, Wu 1999, Mendes 2001, Gouveia et al. 2003, Iwakiri et al. 2003).

However, besides the fact that the assessment of different production variables of panels still do not obtain satisfactory values, the change of these variables still affects strongly the final price of panel. The adhesive is the most expensive component, what makes the definition of its type and quality very important in order to optimize the ratio cost-benefit (Mendes et al. 2010) since that in some cases, the increase of adhesive content looking for the obtainment of OSB panel with better dimensional stability may become impracticable economically.

Such factors reinforce the need to search for new alternatives to obtain dimensional stability of this type of panel, and the thermal treatment is a virtual option, which deserves highlight in this kind of research.

The main objective of this current study was to compare the effect of thermal pre-treatment in particles type strand with the effect of variables of production on the physical-mechanical properties of OSB panels produced with wood from Pinus taeda L., aiming to improve their dimensional stability. 


\section{MATERIAL AND METHODS}

Four trees from the species Pinus taeda L. 35 years old and basic mean density $470 \mathrm{~kg} / \mathrm{m}^{3}$ were used, they were planted in the city of Jaguariaíva-PR (Brazil).

\section{Experimental design}

The experimental design consists in five treatments as described in table 1. Three OSB panels were produced for each treatment, with nominal density of $650 \mathrm{~kg} \cdot \mathrm{m}^{-3}$ and dimensions of $560 \times 560 \times 15,7 \mathrm{~mm}$. particles type strand were produced in the dimensions $0,65 \times 25 \times 90 \mathrm{~mm}$ (thickness, width and length, respectively).

Table 1. Experimental design for the production of OSB panels

\begin{tabular}{cccc}
\hline Treatments & $\begin{array}{c}\text { Thermal } \\
\text { treatments } \\
\text { of particles }\end{array}$ & $\begin{array}{c}\text { Adhesive } \\
\text { content } \\
(\%)\end{array}$ & $\begin{array}{c}\text { Paraffin } \\
\text { content } \\
\text { (\%) }\end{array}$ \\
\hline $\mathrm{T} 1$ & & 6 & - \\
$\mathrm{T} 2$ & $200^{\circ} \mathrm{C}$ & 6 & - \\
$\mathrm{T} 3$ & $240^{\circ} \mathrm{C}$ & 6 & - \\
$\mathrm{T} 4$ & - & 6 & 1 \\
$\mathrm{~T} 5$ & - & 8 & - \\
\hline
\end{tabular}

\section{Thermal treatment of particles}

An electric laboratorial programmable electric-heated forces-air oven was used to make the thermal treatment of strand particles, with automatic control of heating time and temperature. Particles previously dried at a moisture content of 3 to $4 \%$ were placed in trays which were put inside of two independent rectangular metallic boxes, bearing detachable front covers. The boxes containing five trays with particles accommodated adequately and thermocouples type $\mathrm{K}$ were installed in one of them. After they have been closed, the boxes were put in the forced air oven.

Each box has three independent holes on the superior wall. One of these holes is intended to allow the nitrogen injection inside the box through a hose connected to a nitrogen balloon outside the electric-heated forces-air oven. The other hole is intended to allow the oxygen output from the box and the electric-heated forces-air oven displaced in function of the nitrogen injection through another hose. The third hole, allows the possible insertion of thermocouples in order to follow the changes of temperature in different points inside the box. In this study, that hole was sealed and the thermocouples were inserted through the door of one of the boxes, which contained a silicone rubber that avoided the damage of the thermocouples and also provided a better seal and adequate distribution of the thermocouples, which were coupled to a system of data acquisition, monitoring five trays of one of the boxes.

The thermal treatments applied to the particles started with the heating of the electric-heated forces-air oven from room temperature up to $100^{\circ} \mathrm{C}$ at a rate of $3.33^{\circ} \mathrm{C}$ per minute, which took approximately 30 minutes. Afterwards, the heating rate of $1^{\circ} \mathrm{C}$ per minute was employed until the temperature stipulated for the treatment $\left(200\right.$ or $\left.240^{\circ} \mathrm{C}\right)$. The effective thermal treatment time of the particles, for both temperatures, was 60 minutes, counting from the moment at which the stipulated temperature was reached inside the monitored trays. However, for treatment $240^{\circ} \mathrm{C}$, 40 more minutes at $1^{\circ} \mathrm{C}$ per minute was needed to reach to required temperature.

During the thermal treatment of particles at both temperatures and from $160^{\circ} \mathrm{C}$ on, there was a continuous nitrogen injection inside the boxes until the end of process, with a flow of $40 \mathrm{~mL} / \mathrm{minute}$. The nitrogen injection aimed to provide an inert atmosphere inside the boxes and reduce the risk of particles burning, in function of high temperatures that were applied. In the end of each treatment, the forced air oven was turned off and after it is cooling, the environment temperature particles were remove and kept in plastic bags, and then sealed. 
After thermal treatment, and before storage in plastic bags, a random sample was collected, about 200 grams of particles obtained from each of the boxes used in thermal treatments. Samples with approximately 200 grams of particles (control) were also collected before the treatment. After treatment the samples were conditioned $\left(22 \pm 2^{\circ} \mathrm{C}\right.$ and $65 \pm 5 \%$ relative humidity). Their moisture was determined in order to verify the effect of thermal treatment on equilibrium moisture content of the particles.

\section{Manufacture of panels and assessment of their properties}

Panels were produced with Phenol-Formaldehyde adhesive (PF), with solid content of $51.24 \%$, pH 11.89, gel time 8,41 minutes and viscosity $547 \mathrm{cP}$. The quantity of adhesive and paraffin applied were calculated based on the dry mass of particles and their respective contents, according to each treatment, and they are listed on table 1. The application of adhesive and paraffin was done separately in a rotating drum blender, in which there was an air-atomization nozzle used to spray the liquid over the particles.

OSB panels were produced in three layers, which proportions of particles, in mass, were 30:40:30 (face, core and face, respectively). Particles of the internal layer (core) of mattress were oriented perpendicularly in relation to particles of external layers (faces). After particles mattress suffered a cold pre-pressing in a hydraulic press, it was placed in a motorized hydraulic press, with a pressing cycle of: temperature $180^{\circ} \mathrm{C}$, specific pression of 3.5 $\mathrm{MPa}$ and time of 8 minutes, in this process of pressing were used separators with $15 \mathrm{~mm}$ thick which defined the thickness of the panels at the time of pressing. After pressing, OSB panels already consolidated were retired from press and conditioned under temperature of $22 \pm 2^{\circ} \mathrm{C}$ and relative humidity of $65 \pm 5 \%$.

The specimens of OSB panels were obtained with a circular sliding table saw. Dimensions of specimens and proceedings of tests applied on assessment of properties and/or parameters of moisture content of particles and panels, water absorption (WA) after two and twenty four hours of immersion, thickness swelling (TS) after twenty four of immersion, irreversible thickness swell (ITS) and internal bonding (IB), were determined based on the American standard ASTM D 1037 (2006). The standard DIN 52362 (1982) was applied in order to asses MOR and MOE properties of bending on parallel and perpendicular directions. Panel density was determined through the mean density of specimens of all the tests previously mentioned.

Statistical analysis were done in completely randomized design. Variance analysis and the Tukey test were done in order to compare treatments at a probability level of $5 \%$ error. 


\section{RESULTS AND DISCUSSION}

\section{Moisture content of particles and panels, apparent density and thickness of OSB panels}

Mean values of equilibrium moisture content of particles and panels, apparent density and thickness of OSB panels for each treatment can be observed on table 2.

Table 2. Mean values of moisture content, apparent density and thickness of OSB panels

\begin{tabular}{|c|c|c|c|c|c|c|c|c|}
\hline \multirow{3}{*}{ Treatment } & \multicolumn{4}{|c|}{ Moisture content* } & \multirow{2}{*}{\multicolumn{2}{|c|}{$\begin{array}{l}\text { Apparent } \\
\text { density }\end{array}$}} & \multirow{2}{*}{\multicolumn{2}{|c|}{ Thickness }} \\
\hline & \multicolumn{2}{|c|}{ Particles } & \multicolumn{2}{|c|}{ Panels } & & & & \\
\hline & \multicolumn{4}{|c|}{$\%$} & \multicolumn{2}{|c|}{$\mathrm{kg} / \mathrm{m}^{3}$} & \multicolumn{2}{|c|}{$\mathbf{m m}$} \\
\hline Control & 11.25 & $\mathrm{C}$ & 8.55 & $\mathrm{C}$ & 746 & $\mathrm{AB}$ & 14.95 & $\mathrm{AB}$ \\
\hline $200^{\circ} \mathrm{C}$ & 8.37 & B & 7.64 & $\mathrm{~B}$ & 719 & $\mathrm{BC}$ & 15.61 & $\mathrm{BC}$ \\
\hline $240^{\circ} \mathrm{C}$ & 5.73 & A & 5.98 & A & 694 & $\mathrm{C}$ & 15.96 & $\mathrm{C}$ \\
\hline $1 \%$ paraffin & - & - & 8.65 & $\mathrm{CD}$ & 747 & $\mathrm{AB}$ & 14.45 & A \\
\hline $8 \%$ adhesive & - & - & 8.76 & $\mathrm{D}$ & 752 & $\mathrm{~A}$ & 14.58 & $\mathrm{~A}$ \\
\hline $\mathrm{CV}(\%)$ & 3.99 & & 0.76 & & 1.64 & & 2.09 & \\
\hline
\end{tabular}

Means with the same letter do not differ statistically by Tukey test $(\alpha=0.05)$. Moisture content of particles for treatments with application of $1 \%$ of paraffin and with adhesive increase for $8 \%$ is the same used for the control treatment. *moisture content obtained in climate room with temperature of $22 \pm 2^{\circ} \mathrm{C}$ and relative humidity of $65 \pm 5 \%$.

According to table 2 it is possible to see significant differences between equilibrium moisture content of treated particles at temperatures 200 and $240^{\circ} \mathrm{C}$, and also in relation to particles without thermal treatment. Particles treated at $240^{\circ} \mathrm{C}$ presented the lower moisture content and particles treated at $200^{\circ} \mathrm{C}$ present intermediate moisture content. Related to the control, reductions on moisture content were 25.6 and $49.1 \%$ for treatments temperatures of 200 and $240^{\circ} \mathrm{C}$, respectively. The decrease on equilibrium moisture content of particles may be provided by the reduction of accessibility to free hydroxyl groups (sorption sites), as well as by the formation of furfural polymers, which resulted from degradation of sugars (hemicelluloses) and present lower hygroscopicity (Tjeerdsma et al. 1998, Tjeerdsma and Militz 2005). Among hemicelluloses reduced, arabinan and galactan are the most affected, which results in reduction of the higroscopity (Winandy and Krzysik 2007).

The same differentiation was verified for moisture found on panels, and mean moisture content were produced by thermal treatment of particles significantly lower than the obtained for panels of the other treatments, making evident that the thermal treatment of particles, besides reducing its own moisture content, reduced moisture content of produced panels. The reduction of moisture found on panels of treatments produced with treated particles at 200 and $240^{\circ} \mathrm{C}$, in relation to panels of control treatment, were $10.6 \%$ e $30.1 \%$, respectively.

It is also possible to affirm through the results that the variables of production (application of paraffin and increase on adhesive content) tend to increase the mean value of moisture content, being significant in the case of adhesive content.

Analyzing the apparent density of panels (Table 2) it was observed a significant difference among treatments. Panels that received thermal pre-treatment amounted statistically and presented a trend to reduce their mean values of density in relation to the others. This trend had more pronounced effects for panels produced with particles treated at $240^{\circ} \mathrm{C}$, making possible to observe a significant statistical difference of this treatment in relation to control and those that had changes on variables of production. Still analyzing table 2, it was verified a significant difference 
among mean values of panel thickness. Panels that received thermal pre-treatment amounted statistically and presented a trend to increase mean values of thickness in relation to the others, and this trend was not significant only in the comparison of panels produced with particles treated at $200^{\circ} \mathrm{C}$ and control panels.

Considering that the increase of thickness implies on the panel volume and that panel density is given by the ratio between mass and volume, it is possible to infer that the trend of reduction on density of panels produced with particles produced with pre-treatment resulted mainly from the verified increase of thickness.

The increase of thickness may be resulted from the partial liberation of compressive stress occurred right after the end of pressing in the panel production phase. Despite of the mass of particles be the same for all the panels, it was verified a relative increase on the volume occupied by the particles thermally treated and consequently, of the height of the mattress formed by these particles, what proportioned higher compressive stress. The increase on volume verified is an indicative that density of particles probably was reduced in function of thermal degradation of wood. Paul et al. (2007) affirm that thermal treatment on strand particles provides the loss of mass. At the temperature $180^{\circ} \mathrm{C}$ and time 50 minutes it was observed the weight loss of until $0.5 \%$, while at the temperature of $220^{\circ} \mathrm{C}$ and time of 15 minutes, the loss was about $2 \%$. Authors attributed this fact to the thermal degradation of some wood polymers, especially polyoses.

\section{Physical properties}

Mean values of water absorption of OSB panels after two and twenty four hours of immersion (WA2h e WA24h), values of thickness swelling after two and twenty four hours of immersion on water (TS2h e TS24h), as well as of irreversible thickness swell (ITS) for each treatment can be observed on table 3.

Table 3. Mean values of water absorption, thickness swelling and rate of non-return of thickness on OSB panels

\begin{tabular}{|c|c|c|c|c|c|c|c|c|c|c|}
\hline \multirow{2}{*}{ Treatment } & \multicolumn{2}{|c|}{ WA2h } & \multicolumn{2}{|c|}{ WA24h } & \multicolumn{2}{|c|}{ TS2h } & \multicolumn{2}{|c|}{ TS24h } & \multicolumn{2}{|c|}{ ITS } \\
\hline & \multicolumn{10}{|c|}{$\%$} \\
\hline Control & 33.0 & B & 39.4 & BC & 20.7 & C & 23.6 & BC & 17.3 & BC \\
\hline $200^{\circ} \mathrm{C}$ & 38.4 & C & 42.0 & C & 23.6 & & 25.4 & C & 20.1 & C \\
\hline $240^{\circ} \mathrm{C}$ & 25.0 & A & 36.0 & A & 8.5 & A & 11.8 & A & & A \\
\hline $1 \%$ paraffin & 23.7 & $\mathrm{~A}$ & 37.3 & $\mathrm{AB}$ & 16.5 & B & 23.4 & $\mathrm{BC}$ & 17.1 & B \\
\hline $8 \%$ adhesive & 28.5 & $\mathrm{AB}$ & 36.5 & A & 19.0 & C & 21.8 & B & 15.2 & B \\
\hline CV (\%) & 6.50 & & 2,76 & & 4,83 & & 4.93 & & 7.07 & \\
\hline
\end{tabular}

According to the data of table 3 for the properties WA2h and WA24h, the better treatments were those with thermal pre-treatment at $240^{\circ} \mathrm{C}$, with application of paraffin and increase of adhesive content. This allows affirming that the effect obtained for these properties with thermal treatment at $240^{\circ} \mathrm{C}$ is the same that the effect obtained with the changes on production variables.

Reductions on mean values of WA2h of these treatments in relation to the control were $24.2 \%, 28.2 \%$ and $13.6 \%$, respectively. Despite of this, on the property WA2h panels produced with the increase of adhesive content were statistically equal to the control treatment, while on the property WA24h panels produced with application of paraffin were statistically equal to the control treatment.

It is also observed that there was a significant difference between treatments for the properties TS2h, TS24h and ITS. Panels produced with particles treated at $240^{\circ} \mathrm{C}$ differed significantly from all the other treatments and they showed the best performance, presenting the lowest mean values of TS2h, TS24h and ITS. Mean values reduction of the properties of panels with thermal pre-treatment at $240^{\circ} \mathrm{C}$ in relation to panels of control treatment, were $58.9 \%$, $50.0 \%$ and $51.2 \%$, respectively. According to Winandy and Krzysik (2007), evaluated the effects of temperature 
and pressing duration on the properties of MDF panels, reducing the thickness swelling is the result of reduction of the hemicellulose, which promotes the inhibition of moisture absorption.

On the analysis of treatment produced with particles treated thermally at $200^{\circ} \mathrm{C}$ the effect was negative, what made this treatment statistically different from control panels on the properties WA2h and TS2h, obtaining the highest values for these properties. This fact may be related to some chemical degradation process of the particles exposed to temperature, which should be better evaluated in future studies.

However, differently from the obtained in this study, Goroyias and Hale (2002), assessing the effect of thermal treatment in strand particles at temperatures of $200,210,220,230,250,260^{\circ} \mathrm{C}$ during 20 minutes, it has been observed that the temperature increase promoted a significant reduction of thickness swelling. The reason of such difference may be related to the shorter time of treatment, besides other variables of process used for the production of OSB panels.

In the case of increasing the adhesive content ( $8 \%$ of adhesive) for the properties TS2h, TS24h and ITS, it was not observed a significant effect in relation to control panels ( $6 \%$ adhesive) in none of these properties, despite of certain trend to improve. Whilst for the application of paraffin there was a significant improve in relation to control panels, only for the properties TS2h, and this property differed significantly from panels produced with increases on adhesive content, presenting the lowest mean values of swelling.

In relation to the application of paraffin, the good performance obtained from the properties WA2h and TS2h did not repeat for WA24h and TS24h because these amounted statistically in relation to the control in the last cases. This allows affirming that paraffin lost its effect after a period of exposition to water, as referenced by Moslemi (1974), who affirms that the effect of paraffin on the absorption of water on liquid state is significant only in a short period of time, and this absorption has effect over the property of thickness swelling.

The standard CSA 0437 (1993) states only values for the property thickness swelling after twenty four hours of immersion, and the maximum value stipulated of $10 \%$ for panels with thickness superior to $12,7 \mathrm{~mm}$.

Therefore, panels of all treatments adopted by this study revealed mean values of TS24h above maximum (10\%) specified by the standard CSA 0437 (1993), however, the panels produced with particles treated at $240^{\circ} \mathrm{C}$ presented the nearest value $(11.8 \%)$ of the required by this property.

\section{Mechanical properties}

Mean values of internal bonding and modulus of rupture (MOR) and modulus of elasticity (MOE) to bending in parallel and perpendicular directions, for each treatment can be observed on table 4 . 
Table 4. Mean values of internal bonding, modulus of rupture (MOR) and modulus of elasticity (MOE) and bending of OSB panels

\begin{tabular}{|c|c|c|c|c|c|c|c|c|c|c|}
\hline \multirow{3}{*}{ Treatment } & \multicolumn{4}{|c|}{ MOR } & \multicolumn{4}{|c|}{ MOE } & \multicolumn{2}{|c|}{$\begin{array}{l}\text { Internal } \\
\text { bonding }\end{array}$} \\
\hline & \multicolumn{2}{|c|}{ Parallel } & \multicolumn{2}{|c|}{ Perpendicular } & \multicolumn{2}{|c|}{ Parallel } & \multicolumn{2}{|c|}{ Perpendicular } & & \\
\hline & & & & & MP & & & & & \\
\hline Control & 57.50 & A & 20.82 & A & 8061.18 & A & 2022.31 & $\mathrm{AB}$ & 0.60 & A \\
\hline $200^{\circ} \mathrm{C}$ & 30.79 & B & 10.67 & B & 5570.40 & B & 1293.78 & $\mathrm{C}$ & 0.23 & B \\
\hline $240^{\circ} \mathrm{C}$ & 27.84 & B & 13.07 & B & 5934.29 & B & 1554.12 & $\mathrm{BC}$ & 0.30 & B \\
\hline $1 \%$ paraffin & 45.67 & $\mathrm{AB}$ & 24.11 & A & 7525.71 & $\mathrm{AB}$ & 1993.04 & $\mathrm{AB}$ & 0.60 & A \\
\hline $8 \%$ adhesive & 57.59 & $\mathrm{~A}$ & 25.86 & A & 9401.3 & $\mathrm{~A}$ & 2434.71 & $\mathrm{~A}$ & 0.64 & $\mathrm{~A}$ \\
\hline CV (\%) & 15.99 & & 14.90 & & 10.29 & & 12.14 & & 13.89 & \\
\hline
\end{tabular}

Means with the same letter do not differ statistically by Tukey test $(\alpha=0.05)$.

According to the data of table 4 it was observed a significant difference among treatments for all mechanical properties evaluated. In the properties MOR parallel and perpendicular, panels produced with particles thermally treated at temperatures 200 and $240^{\circ} \mathrm{C}$ did not present significant differences, however they differ from control treatment, obtaining lower mean values. Reductions observed on treatments produced with particles treated at 200 and $240^{\circ} \mathrm{C}$ in relation to control panels were for MOR parallel of $46.5 \%$ and of $51.6 \%$, respectively, while for MOR perpendicular reductions were $48.8 \%$ and of $37.2 \%$, respectively. Paul et al. (2006), assessing the effect of thermal treatment of strand particles at temperatures 220 and $240^{\circ} \mathrm{C}$ also observed the reduction of MOR about $35-50 \%$. In the property MOE parallel, panels produced with particles thermally treated at 200 and $240^{\circ} \mathrm{C}$ did not present significant differences among each other and among panels with application of $1 \%$ of paraffin, but this property was reduced significantly in relation to control treatments and with an increase of adhesive content. While in MOE perpendicular, panels produced with particles thermally treated did not differ among themselves, but panels produced with particles treated at $240^{\circ} \mathrm{C}$ were statistically equal to control panels and those produced with addition of $1 \%$ of paraffin.

Reductions observed on treatments produced with particles treated at 200 and $240^{\circ} \mathrm{C}$ in relation to control panels for MOE parallel were $30.9 \%$ and of $26.4 \%$, respectively, while for MOE perpendicular reductions were $36.0 \%$ and of $23.2 \%$, respectively.

Paul et al. (2006), assessing the effect of thermal treatment at temperatures of 220 and $240^{\circ} \mathrm{C}$ applied to strand particles, verified for OSB panels produced with Phenol-Formaldehyde the decrease of MOE at two temperatures. But as observed in this study, it was found that this property trend to increase at the temperature of $240^{\circ} \mathrm{C}$ in relation to the other temperature of treatment. It is also observed that on thermal pre-treatment the MOE trending to decrease is lower than MOR, what also was observed by several authors (Pavlo and Niemz 2003, Paul et al. 2006, Shi et al. 2007).

For internal bonding property, panels produced with particles thermally treated did not show a significant difference among themselves, but they differed from other treatments, obtaining the lowest mean values. Reduction of panels produced with particles treated at 200 and $240^{\circ} \mathrm{C}$ in relation to control panels were 61.7 and $50.0 \%$, respectively. According to Sernek et al. (2004), the reason of the decrease on such treatment, in consequence of heat exposition, may be related to extractive moving for the particle surface and inactivation of wood surface. The author affirms that the effect is more pronounced on wood of species like Pinus taeda L. bonded with PhenolFormaldehyde adhesive, which was the situation of this study.

In relation to adhesive content and application of paraffin, it was not observed a significant statistical difference among these treatments and control treatment. Gouveia et al. (2003), assessing three types of mattress structure and three levels of phenolic adhesive on the production of OSB panels, also did not observe significant statistical 
difference for the contents 6 and $8 \%$ of adhesives on the properties MOR and MOE parallel and perpendicular, and internal bonding. But as in this study, they observed a trend of increase on these properties as adhesive content grows.

In relation to the paraffin application, despite of it was not observed a statistical difference in relation to control treatment, there was a trend to decrease MOR and MOE properties parallel and perpendicular. This trend of decrease provides statistical equality in relation to panel produced with particles thermally treated. Iwakiri et al. (2003), verifying the effect of three paraffin contents $(0 ; 0,5$ e $1 \%)$ on the production of OSB panels with $6 \%$ of Phenol-Formaldehyde adhesive also did not observe significant effect, but a trend to decrease mechanical properties.

The standard CSA 0437 (1993) states as minimum values of MOR parallel 28.4 and 22.9 MPa for the classifications O-2 e O-1, respectively. For MOR perpendicular, values are 12.2 and $9.4 \mathrm{MPa}$, respectively. For MOE parallel of 5393.7 and 4413.0 MPa for classifications O-2 and O-1, respectively. For MOE perpendicular, 1471.0 and $1274.9 \mathrm{MPa}$, respectively. For internal bonding, the minimum value stipulated for classifications $\mathrm{O}-2$ and $\mathrm{O}-1$ is $0.34 \mathrm{MPa}$.

Therefore, for the property MOR parallel, only panels produced with particles treated at $240^{\circ} \mathrm{C}$ attended classification O-1, while the other treatments attended the classification O-2. For MOR and MOE perpendicular, only panels produced with particles treated at $200^{\circ} \mathrm{C}$ attended classification $\mathrm{O}-1$, while other treatments attended classification O-2. For MOE parallel, all treatments attended classification O-2. For internal bonding, panels produced with treated particles did not attend the standard.

\section{CONCLUSIONS}

Thermal treatment of particles at $240^{\circ} \mathrm{C}$ resulted in panels with better performance on physical properties compared to panels produced with particles thermally treated at $200^{\circ} \mathrm{C}$. For mechanical properties of panels it was not observed significant differences among these two temperatures of pre-treatment. In relation to control panels, thermal treatment of particles at $200^{\circ} \mathrm{C}$ promoted a negative effect on physical and mechanical properties, while thermal treatment at $240^{\circ} \mathrm{C}$ promoted a significant improvement of physical properties and reduction of mechanical properties.

The increase of adhesive and application of paraffin, in relation to control treatment, did not promote a significant improvement in none of the mechanical property of panels. However, for physical properties the increase of adhesive content resulted in a significant improvement of WA24h, and the application of paraffin in an improvement of WA2h and TS2h of panels.

In the comparison between thermal pre-treatment and production variables (increase of adhesive content and application of paraffin) over dimensional stability of panels, it was observed that the improvement of adhesive content and application of paraffin did not provide a pronounced improvement of the panels' stability when compared to thermal treatment applied to particles at $240^{\circ} \mathrm{C}$.

In order to improve the knowledge about the effect of thermal pre-treatment on physical-mechanical properties of OSB panels in future works, it is recommended to assess different times of treatment and levels of temperature on thermal pre-treatment of particles, in addition to assess possible changes on anatomical and chemical characteristics of wood particles. 


\section{REFERENCES}

ASTM, American Society for Testing and Material. 2006. Standard methods of evaluating properties of wood-base fiber and particles materials. In: Annual book of Standards American. Philadelphia, ASTM D-1037.pp. 1-30.

Brito, J.O.; Garcia, J.N.; Bortoletto Jr, G.; Pessoa, A.M.C.; Silva, P.H.M. 2006. Densidade básica e retratibilidade da madeira de Eucalyptus grandis, Submetida a diferentes temperaturas de termorretificação. Cerne 12(2):182-188.

Bourgois, J.; Guyonnet, R. 1988. Characterization and analysis of torrified wood. Wood Science and Technology 22(2): 143-155.

Byrne, C.E.; Nagle, D.C. 1997. Carbonization of wood for advanced materials applications. Carbon 35(2):259-266.

C.S.A. Canadian Standards Association. 1993. OSB and waferboard: CSA 0437-0. Ontario, 18p.

Chang, H.T.; Chang, S.T. 2003. Improvements in dimensional stability and lightdastness of wood by butyrylation using microwave heating. Journal of Wood Science 49(5): 455-460.

Chen, Y.; Choong, E.T.; Barnes, H.M.1995. Effect of selected water - soluble bulking chemicals on moisture diffusion and dimensional stability of wood. Forest Products Journal 45(5): 84-90.

Del menezzi, C.H.S. 2004. Estabilização dimensional por meio do tratamento térmico e seus efeitos sobre as propriedades de painéis de partículas orientadas (OSB). Ph.D. Thesis in Universidade Federal do Paraná, Curitiba, Brazil.

DIN. Deutsches Institut für Normung. 1982. Testing of wood chipboards bending test, determination of bending strength: DIN 52362. Berlin. 40p.

Gohar, P.; Guyonet, R. 1998. Development of wood rectification process at the industrial stage. In: Proceedings International Symposium on Wood Preservation, 4, Cannes, France, p. 173-178.

Goroyias, GJ.; Hale, MD. 2002. Heat treatment of wood strands for OSB production: Effect on the mechanical properties, water absorption and dimensional stability. In: Annual Meeting International Research Group on Wood Preservation, Proceedings, 33, Cardiff, Wales, UK, p18.

Gouveia, N.F.; Santana, M.A.E.; Souza, M.R. 2003. Utilização da madeira de Eucalyptus grandis W. Hill ex Maiden e Eucalyptus urophylla S.T. Blake na fabricação de chapas de partículas orientadas (OSB) e não orientadas. Rev Árvore 24 (1): 7-12.

Hill, C.A.S.; Mallon, S. 1999. The chemical modification of scots pine with succinic anydride or octenyl succinic anhydride. I. Dimensional stabilization. Holzforschung 52(4):427-433

Hillis, W.E. 1984. High temperature and chemical effects on wood stability. Part 1: General considerations. Wood Science and Technology 18(4):281-293.

Homan, W.; Tjeersdsma, B.; Beckers, E.; Jorissen, A. 2000. Structural and other properties of modified wood. In: World Conference on Timber Engineering, Proceedings. British Columbia, p. 1-8. 
Iwakiri, S.; Mendes, L.M.; Saldanha, L.K. 2003. Produção de chapas de partículas orientadas OSB de Eucalyptus grandis com diferentes teores de resinas, parafina e composição de camadas. Ciência Florestal 13(1): 89-94.

Kelly, M.W. 1977. A critical literature review of relationships between processing parameters and physical properties of particleboards. For. Prod. Lab. General Technical Report, FPL-10, Madison, United Stated.

Kim, GH.; Yun, KE.; Kim, JJ. 1998. Effect of heat treatment on the decay resistance and the bending properties of radiata pine sapwood. Material und Organizem 32(2):101-108.

Kubojima, Y.; Okano, T.; Ohta, M. 2000. Bending strength and toughness of heat-treated wood. Wood Science and Technology 46(1): 8-15.

Maloney, T.M. 1993. Modern particleboard e dry-process fiberboard manufacturing. Hal Leonard Corporation, United States.

Mendes, LM. 2001. Pinus spp. na produção de painéis de partículas orientadas (OSB). Ph.D. Thesis in Universidade Federal do Paraná, Curitiba, Brazil.

Mendes, RF.; Mendes, LM.; Abranches, RAS.; Santos, RC.; Guimarães júnior, JB. 2010. Painéis aglomerados produzidos com bagaço de cana em associação com madeira de eucalipto. Scientia Forestalis 38 (86): 285-295.

Momohra, I.; Ohmura, W.; Kato, H.; Kubojima, Y. 2003. Effect of high-temperature treatment on wood durability against the Brown-rot fungus, Fomitopsis palustris, and the térmite, Coptotermes formosanus. In: International IUFRO wood drying conference. Proceedings, 8, Kanazawa. Kanazawa, Japan, p 284-287.

Moslemi, A.A. 1974. Particleboard. Southern Illinois University Press, 2 v, London.

Murakami, K.; Ueda, M.; Matsuda, H.; Zhang, M.; Kawasaki, T.; Kawai, S. 1999. Manufacture and properties of three-layered particleboards with oriented face strands of veneers I. Journal of Wood Science 45(5): 395-402.

Paul, W.; Ohlmeyer, M.; Leithoff, H.; Boonstra, M.J.; Pizzi, A. 2006. Optimising the properties of OSB by a one-step heat pre-treatment process. Holz als Roh- und Werkstoff 64 (3): 227-234.

Paul, W.; Ohlmeyer, M.; Leithoff, H. 2007. Thermal modification of OSB-strands by a one-step heat pre-treatment - Influence of temperature on weight loss, hygroscopicity and improved fungal resistance. Holz als Roh- und Werkstoff 65(1): 57-63.

Paz, J.J.; Sanabria, E.O. 2000. Dimensional stabilization of Aspidosperma quebracho blancowith polyethylene glycol. In: Proceedings IUFRO world congress, 3, Kuala Lumpur, Malaysia, p.236.

Pavlo, B.; Niemz, P. 2003. Effect of temperature on color and strength of spruce wood. Holzforschung 57(5): 539-546.

Pessoa, AMC.; Berti Filho, E.; Brito, JO. 2006. Avaliação da madeira termorretificada de Eucalyptus grandis, submetida ao ataque de cupim de madeira seca, Cryptotermes brevis. Scientia Forestalis 72 (3):11-16

Rousset, P.; Perré, P.; Girarsd, P. 2004. Modification of mass transfer properties in poplar wood (P. robusta) by thermal treatment at high temperature. Holz als Roh-und Werkstoff 62 (2): 113-119. 
Rowell, R.M.; Youngs, R.L. 1981. Dimensional stabilization of wood in use. For. Prod. Lab. General Technical Report, FPL-243, Madison, United Stated.

Santos, J.A. 2000. Mechanical behaviour of eucalyptus wood modified by heat. Wood Science and Technology 34 (1): 39-43.

Sernek, M.; Kamke, A.F.; Glasser, W.G. 2004. Comparative analysis of inactivated wood surface. Holzforschung 58 (1): 22-31.

Shi, J.L.; Kocaefe, D.; Zhang, J. 2007. Mechanical behaviour of Québec wood species heat-treated using thermo wood process. Holz als Roh-und Werkstoff 65(4):255-259.

Spelter, H.; Mckeever, D.; Alderman, M. 2006. Status and Trends: Profile of Structural Panels in the United States and Canada. Department of Agriculture. For. Prod. Lab. General Technical Report, FPL-636, Madison, United Stated.

Stamm, A.J. 1956. Thermal degradation of wood and cellulose. Industrial and Engineering Chemistry 48 (3): 413-417.

Tjeerdsma, B.F.; Militz, H. 2005. Chemical changes in hydrothermal treated wood: FTIR analysis of combined hydrothermal and dry heat-treated wood. Holz als Roh-und Werkstoff 63 (2): 102-111.

Tjeerdsma, B.F.; Boonstra, M.; Pizzi, A.; Tekely, P.; Militz, H. 1998. Characterization of Thermally Modified Wood: Molecular Reasons for Wood Performance Improvement. Holz als Roh-und Werkstoff 56 (3): $149-153$.

Winandy, J.E.; Krzysik, A.M. 2007. Thermal degradation of wood fibers during hot-pressing of MDF composites: part I. relative effects and benefits of thermal exposure. Wood and Fiber Science 39(3):450-461.

Wu, Q. 1999. In-plane dimensional stability of oriented strand panel: effect of processing variables. Wood and Fiber Science 31(1):28-40. 